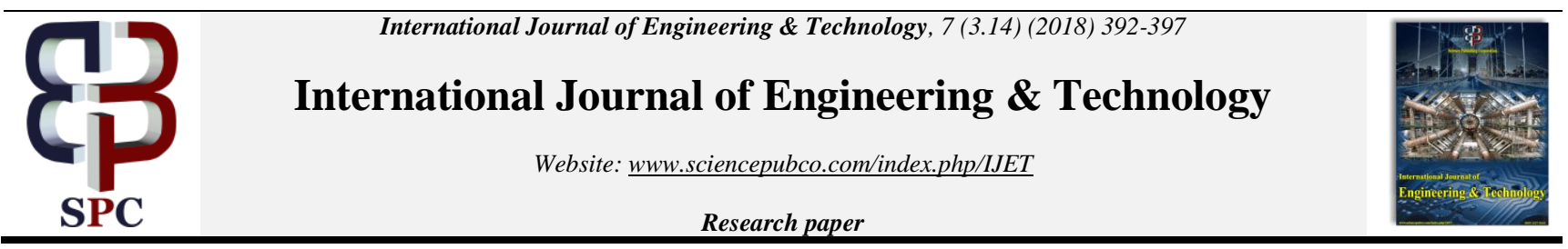

\title{
The Assessment of the Investment Potential of the Insurance Sector of the Region in the Conditions of Risk and Uncertainty
}

\author{
Olga Alekseevna Okorokova ${ }^{1}$, Lubov Konstantinovna Ulibina ${ }^{2}$, Polina Alekseevna Maksimenko ${ }^{3}$, \\ Mikhail Gennadevich Rusetskiy ${ }^{4}$, Galina Ivanovna Lazareva ${ }^{5}$ \\ 1 Kuban State Agrarian University (Kuban SAU) \\ Kalinina street, 13, Krasnodar, 350044, Russia \\ 2 Kuban State Agrarian University (Kuban SAU) \\ Kalinina street, 13, Krasnodar, 350044, Russia \\ 3 Kuban State Agrarian University (Kuban SAU) \\ Kalinina street, 13, Krasnodar, 350044, Russia \\ 4North Caucasus Federal University (NCFU) \\ Pushkina Streel, 1, Stavropol, 355009, Russia \\ 5Stavropol Institute of Cooperation (Branch) Belgorod University of Cooperation, Economics and Law (BUKEP) \\ Goleneva Street, 36, Stavropol, 355000, Russia
}

\begin{abstract}
Krai; the problems of its development are revealed as well. It is proved that in the conditions of risk and uncertainty it is especially important to distinctively define the role of the insurance sector of the financial market, to determine its interaction with the real sector branches of the regional economy by means of using the industrial, social and investment potential. Modern insurance relations are formed under the influence of the transformation processes in the development of the financial system, institutions and instruments of the insurance sector; they are determined by the methods of state regulation as well. Underestimating the problems of the insurance market in the reproduction process of the regional economy negatively affects its development. In this regard it is essential to develop and implement a qualitatively new strategy of the development of the insurance market and its infrastructure that could be oriented towards modern achievements. At the same time the reproductive, investment approach to the insurance strategy should be implemented. The authors have developed a factorial model of the assessment of the investment potential of the regional insurance market in the context of socio-economic transformation of the development institutions. The main vectors of the development of the regional insurance market on the basis of the economic potential of the region are suggested.
\end{abstract}

Keywords: insurance sector, investment potential, region, transformation, risk, uncertainty.

\section{Introduction}

The peculiar character of the evolution of the regional insurance market is due to the historical prerequisites.

The process of the formation of the regional insurance markets has been comparatively balanced since 1990s. The regional insurance institutions were established not only in Moscow and Saint Petersburg but also in other Russian regional economic centres. Nevertheless, in the process of its sustained evolution the insurance market of the region underwent significant changes which were interconnected with the decreasing number of insurance institutions in general and with their diminishing market capitalisation. The catagenesis of capital outflow from the region and its concentration in the centres became the basis of the abovementioned changes; they were also due to the process of increasing competitiveness between the branches of global and major insurance companies from other regions.

\section{The Methodology of the Research}

Is extremely hard to determine the investment and economic potential of a region specifically; in the context of traditional debates it is a systematic indicator that is formed under the influence of particular factors of political, economic, socio-demographic nature as well as technogenic and many other factors.

The following negative factors contribute to the increasing imbalance in the insurers' deployment: the lack of highly qualified personnel, difficulties in forming authorised capital due to the increasing requirements for its amount, the decreasing production potential of the regional economy.

Insurance companies that act at the regional level are mainly faced with the issues of interaction at the level of regional administration.

Authorities try to attract insurance companies to participation in investment processes in different ways. In some cases, the attempts to use administrative methods though the prism of legal regulation can be noticed.

In the context of presented circumstances, it is worth remembering that insurance companies must be responsible for the commitments made to preserve and strengthen the positions on the market as well as guarantee safety of financial resources entrusted to insurers. 


\section{The Results of the Research}

The investment policy of the branches of insurance companies from other regions is formed and implemented in the main offices of companies.

In certain periods the outflow of funds from the branches is possible, whereas the inflow of funds into a region via insurance channels is possible at the other ones. In any case, the regulation of investment activity of insurance institutions at the regional level is achievable by means of normative requirements for depositing insurance resources.

Among immanent institutions which contribute to the inflow of investment resources we can single out the transferring of new financial assets and their elements into the equity market; observance of business transparency; improvement and adaptation of international standards of accounting.

Specific features of insurance markets of a region can include a significant proportion of medium-sized and small institutions and consequently, a problem of low insurance resources sufficiency, capitalisation of regional insurers and their provision with insurance resources in comparison with Russia in general is much lower.

Before the introduction of the mechanism of mandatory liability insurance regional insurance markets did not experience a significant need in establishing and developing additional insurance institutions.

Based on the insurance potential of the investment sector, essential peculiarities of productive and investment development of the region, the authors systemised the factorial structure of the resource potential of the insurance sector of the region.
Proceeding from the factorial analysis of the composition of productive and investment potential of the region, it is advisable to consider the further development of the regional insurance sector.

The guarantee of safety and stability in improvement of entrepreneurship on the basis of implementing innovative mechanisms of insurance protection is becoming a critical requirement for effective functioning of national economy.

Presently the active evolution of the insurance services market can be noted in the regions, which allows forming a system of protecting property interests of economic entities and citizens from technogenic, natural, economic and other risks that ensures socioeconomic stability and security of regional economic systems.

In the works of the following Russian and foreign scientists the consideration of new economic models of problems in forming and developing insurance regional markets can be traced: N.V. Kirillova, T.P Mevdedeva, A.V. Penyugalova, L.A Rusetskaya, A.K. Sembekov, Yu. E. Slepukhina, S.E. Shipitsina and others.

However, the problems of developing investment and insurance potential of insurance market institutions, the issues of forming effective models of their influence in terms of the specifics of functioning of regional economy have not been studied enough.

Krasnodar Krai can be characterised as a dynamically developing region. According to ranking assessments, an investment attractiveness of Krasnodar Krai occupies the eighth place in the Russian Federation. In 2016 there was a growth in economic opportunities in terms of the amount of gross regional product up to 2134 billion Russian roubles that characterises an increased scope in the economic development of the region from the standpoint of the volumes of goods and services production (Table 1) [12,13].

Table 1. The investment opportunities of forming insurance sector in Krasnodar Krai [12, 13].

\begin{tabular}{|l|l|l|l|l|l|l|l|l|l|l|}
\hline Indicators & 2009 & 2010 & 2011 & 2012 & 2013 & 2014 & 2015 & 2016 \\
\hline $\begin{array}{l}\text { The amount of } \\
\text { gross regional product (billions of Russian roubles) }\end{array}$ & 874 & 998 & 1008 & 1552 & 1600 & 1500 & 1947 & 2134 \\
\hline $\begin{array}{l}\text { Gross regional product per capita (thousands of Rus- } \\
\text { sian roubles) }\end{array}$ & 169 & 193 & 226 & 310 & 320 & 308 & 355 & 383 \\
\hline $\begin{array}{l}\text { The amount of fixed assets (billions of Russian rou- } \\
\text { bles) }\end{array}$ & 1870 & 2139 & 2138 & 2821 & 3639 & 4208 & 4770 & 5481 \\
\hline $\begin{array}{l}\text { Cost of shipped goods of own production, completed } \\
\text { works in industry (billions of Russian roubles) }\end{array}$ & 330 & 442.7 & 527.3 & 602.4 & 670.4 & 781.1 & 919.3 & 940.2 \\
\hline $\begin{array}{l}\text { The amount of investments into fixed assets (billions } \\
\text { of Russian roubles) }\end{array}$ & 358 & 589 & 651 & 798 & 955 & 750 & 586 & 429 \\
\hline $\begin{array}{l}\text { The amount of retail trade (billions of Russian rou- } \\
\text { bles) }\end{array}$ & 552 & 646 & 753 & 816 & 916 & 1069 & 1160 & 1248 \\
\hline Region's population (thousands) & 5161 & 5225 & 5284 & 5284 & 5284 & 5286 & 5514 & 5571 \\
\hline $\begin{array}{l}\text { The amount of average annual employment in the } \\
\text { regional economy } \\
\text { (thousands) }\end{array}$ & 2627 & 2658 & 2860 & 2860 & 2862 & 2864 & 3106 & 3111 \\
\hline $\begin{array}{l}\text { Average amount of income/expense per capita of the } \\
\text { region's population } \\
\text { thousands) }\end{array}$ & $166 / 162$ & $166 / 138$ & $189 / 146$ & $190 / 146$ & $191 / 147$ & $192 / 148$ & $386 / 310$ & $340 / 356$ \\
\hline $\begin{array}{l}\text { The amount of loans granted to households } \\
\text { (millions of Russian roubles) }\end{array}$ & 106223 & 108224 & 108330 & 108400 & 108500 & 108540 & 103878 & 179100 \\
\hline $\begin{array}{l}\text { Total area of residential premises put into operation } \\
\text { (thousands of square metres) }\end{array}$ & 3412 & 3606 & 3758 & 4371 & 3949 & 4759 & 4644 & 4502 \\
\hline
\end{tabular}

The formation of regional economy in the investment-innovative direction aggravates the instability of the given system that makes it necessary to develop insurance institutions and requires the sufficient level of insurance protection.

The insurance market of Krasnodar Krai can be characterised by excellent development opportunities which are due to the indicators of the development of the economic system of the region.

The persistent tendencies in the insurance market formation in Krasnodar Krai are determined by a high concentration of insurance institutions and their effectiveness in the volumes of collect- ed insurance premiums that contributes to the eighth place of Krasnosar Krai among Russian regions.

The insurance activity on the territory of Krasnosar Krai in 2016 was carried out by 107 insurance institutions.

Among them 2 institutions possess a status of independent regional insurance institutions, 105 are institutions' branches, 30 organisations acted as insurance agents (Table 2) [13-15, 18]. 
Table 2. The formation of insurance sector in Krasnodar Krai

\begin{tabular}{|c|c|c|c|c|c|c|c|c|}
\hline Indicators & 2009 & 2010 & 2011 & 2012 & 2013 & 2014 & 2015 & 2016 \\
\hline Total number of insurance institutions & 137 & 132 & 121 & 130 & 130 & 109 & 107 & 107 \\
\hline Regional insurance institutions & 5 & 5 & 4 & 3 & 3 & 2 & 2 & 2 \\
\hline Branches of insurance institutions & 132 & 127 & 121 & 110 & 91 & 91 & 105 & 105 \\
\hline The amount of insurance reserves (millions of Russian roubles) & 767 & 962 & 967 & 978 & 982 & 998 & 1002 & 1012 \\
\hline The amount of insurance assets (millions of Russian roubles) & 884 & 1050 & 1052 & 1056 & 1062 & 1072 & 1098 & 1099 \\
\hline The amount of expenses on a single insurance case & 58 & 58 & 58 & 56 & 42 & 41 & 39,0 & 38,0 \\
\hline The amount of tax payments of insurance institutions (millions of Russian roubles) & 305 & 283 & 330 & 350 & 365 & 530 & 171.0 & 540.8 \\
\hline
\end{tabular}

There is a continuing capitalisation of the regional insurance market which is manifested in the increasing authorised capital per a single insurance institution from 85 million Russian roubles in 2009 to 240 million Russian roubles in 2014.
The volume of the regional insurance market increased by 2.2 times. At the same time there is a certain instability of indicators which is dependent on the instruments implemented in insurance activities (Table 3) [16].

Table 3. The dynamics and the composition of the insurance portfolio in terms of insurance instruments in Krasnodar Krai (millions of Russian roubles)

\begin{tabular}{|l|l|l|l|l|l|l|l|l|}
\hline Indicators & 2009 & 2010 & 2011 & 2012 & 2013 & 2014 & 2015 & 2016 \\
\hline The total number of insurance premiums & 9421 & 10582 & 13281 & 16952 & 18354 & 20917 & 23047 & 26250 \\
\hline On voluntary insurance instruments & 6288 & 7236 & 9403 & 11783 & 12518 & 13715 & 10803 & 14049 \\
\hline On life insurance instruments & 270 & 369 & 539 & 861 & 1170 & 1524 & 2418 & 3930 \\
\hline On personal insurance instruments & 1579 & 1775 & 2609 & 2872 & 3223 & 2866 & 2947 & 3433 \\
\hline On property insurance instruments & 4393 & 4981 & 6084 & 7077 & 7341 & 8520 & 2748 & 6686 \\
\hline On mandatory insurance instruments & 3133 & 3346 & 3878 & 5169 & 5833 & 7086 & 10642 & 10524 \\
\hline MTPL insurance & 3083 & 3298 & 3835 & 4881 & 5501 & 6918 & 10447 & 10333 \\
\hline Mandatory insurance of dangerous manufacturing facilities & $\mathrm{X}$ & $\mathrm{X}$ & $\mathrm{X}$ & 272 & 226 & 167 & 164 & 103 \\
\hline
\end{tabular}

In Krasnodar Krai in 2016 the amount of insurance premiums on voluntary insurance segment totalled 14049 million Russian roubles, on life insurance instruments - 3930 million Russian roubles, on personal insurance instruments -3433 million Russian roubles, on property insurance instruments -6686 million Rus- sian roubles including MTPL insurance instruments which made 10333 million Russian roubles.

The tendency of insurance payments demonstrates 1.9 times growth and differentiation of the indicator in terms of insurance instruments (Table 4) [17-19].

Table 4. The dynamics and structure of insurance payments on contract commitments of insurance institutions in Krasnodar Krai (millions of Russian roubles)

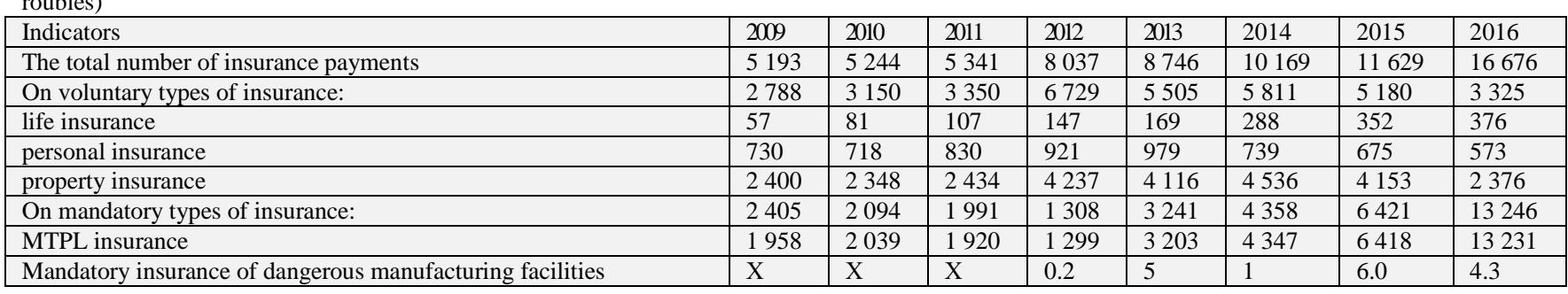

The amount of insurance payments on the insurance instruments in 2016 is presented in the following form: MTPL insurance - 13 231 million Russian roubles (6.7 times increase), life insurance 376 million Russian roubles (6.5 times increase), personal insurance -573 million Russian roubles $(0.7 \%$ increase), property insurance - 2376 million Russian roubles (0.9 times increase).

The conducted research showed that recently there has been a persistent growth in the amount of insurance premiums per capita in Krasnodar Krai.
In the Russian Federation in 2016 the expenses of the population on the insurance products increased up to 8058.70 Russian roubles, however, the given indicator is lower in Krasnodar Krai than the average level in Russia (4 712 Russian roubles in 2016); it is lower than the indicator in the industrial countries of the world insurance market (Figure 1).

A significant increase in the insurance density (insurance premium per capita) in the investigated period is due to the growth in the amount of insurance premium against the background of minor population growth in Russian and in Krasnodar Krai.

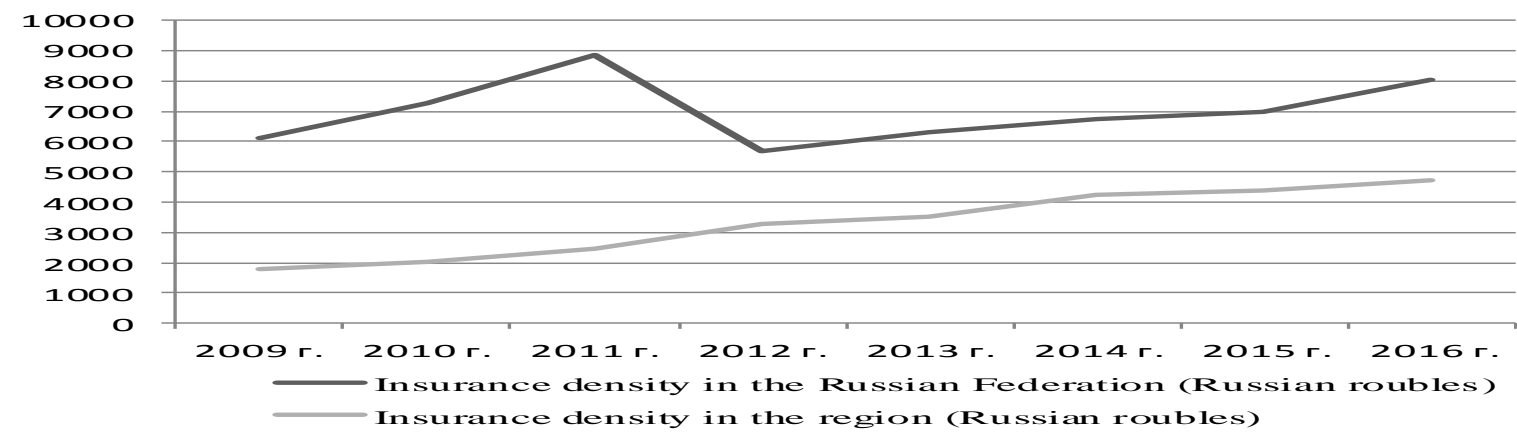

Fig. 1. The dynamic series of the amount of insurance premiums per capita in the Russian Federation and Krasnodar Krai [13, 18] 


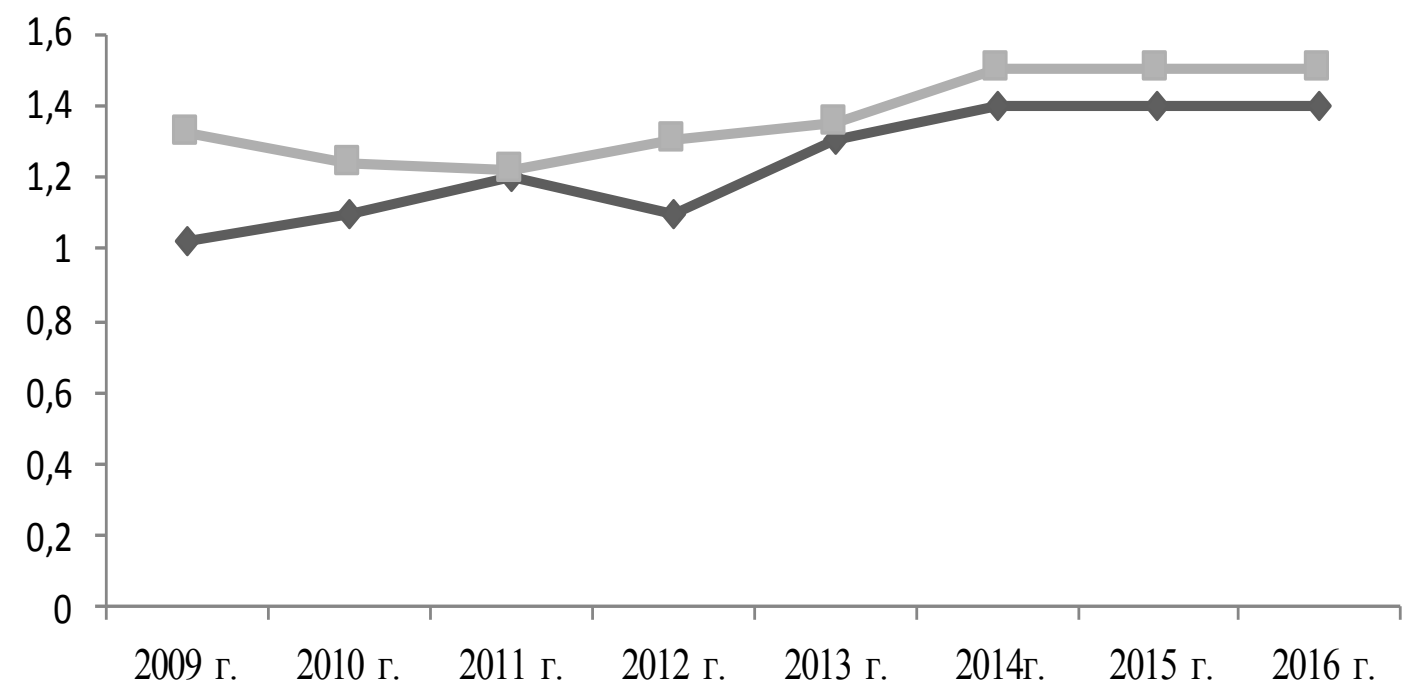

$\rightarrow$ The share of premiums in GRP, $\%-$ The share of premiums in GDP, $\%$

Fig. 2. The dynamic series of the ratio of insurance premiums in GDP and GRP [13, 18].

There is an increase in the proportion of insurance premiums in the gross regional product (GRP) from $1.02 \%$ in 2009 to $1.4 \%$ in 2016 (Figure 2).

Such a decrease is due to the crisis phenomena in the economy, declining volume of production and, consequently, decline in the income of the population.

The process of introduction of long-term kinds of personal insurance services to the insurance services market is rather slow including missed and combined life insurance (old age and death), pension insurance, annuity, rents, etc. The coverage of insurance protection of such a group of the population as children, who are vulnerable to injuries, is not wide enough.

The complex instruments of home insurance, property insurance, household civil liability insurance, KASKO insurance (insurance against damage or carjacking) are not developed well enough.

The programme instruments of the responsibility for the quality of goods, works and services of producers and sellers are not demanded as well as the responsibility of professional private practitioners such as doctors, lawyers, notaries, realtors and architects.
The insurance companies are slowly developing the sphere of insurance for citizens who arrive in Krasnodar Krai for recreation, medical treatment, sports and tourism.

Agricultural insurance is one of the most important segments of the insurance market. The assessment of tendencies of the development of the given sector showed that the amount of collected insurance premiums in 2016 in Krasnodar Krai increased by 3 times compared to 2009 and with state support - by 3.8 times. The volume of the agricultural insurance market in the region totalled 1592 million Russian roubles in 2016 including 1529 million Russian roubles that were received with state support and 63 million Russian roubles were received without state support. The expenses on the subsidising of agricultural risks in the region ranged from 107 to 638 million Russian roubles including allocations from the federal budget ranging from 84.5 to 538 million Russian roubles and from the regional budget ranging from 3 to 100 million Russian roubles (USA - 10 billion US dollars, China -5 billion US dollars) (Table 5) [5, 8, 9, 10].

Table 5. The development of the agricultural insurance segment in Krasnodar Krai

\begin{tabular}{|c|c|c|c|c|c|c|}
\hline \multirow{3}{*}{ Year } & \multicolumn{2}{|c|}{$\begin{array}{l}\text { Insurance premiums, } \\
\text { (millions of Russian rou- } \\
\text { bles) }\end{array}$} & \multirow[t]{3}{*}{$\begin{array}{l}\text { Number of insurance contracts concluded with state } \\
\text { support }\end{array}$} & \multicolumn{3}{|c|}{$\begin{array}{l}\text { Expenses on the subsidising of agricultural insurance in the } \\
\text { region } \\
\text { (millions of Russian roubles) }\end{array}$} \\
\hline & \multirow{2}{*}{ Total } & \multirow{2}{*}{$\begin{array}{l}\text { with state sup- } \\
\text { port }\end{array}$} & & \multirow{2}{*}{ Total } & \multicolumn{2}{|c|}{ Budget level } \\
\hline & & & & & Federal & Regional \\
\hline 2009 & 539.0 & 400.0 & 153.0 & 213.0 & 161.0 & 52.0 \\
\hline 2010 & 574.0 & 216.0 & 46.0 & 107.6 & 84.5 & 23.4 \\
\hline 2011 & 939.0 & 539.0 & 120.0 & 524.0 & 472.0 & 52.0 \\
\hline 2012 & 1312 & 110.0 & 624.0 & 493.0 & 443.0 & 50.0 \\
\hline 2013 & 1433 & 1350.0 & 376.0 & 553.0 & 497.0 & 56.0 \\
\hline 2014 & 1817 & 1637.0 & 374.0 & 638.0 & 538.0 & 100.0 \\
\hline 2015 & 1167.3 & 1068.8 & 144.0 & 358.0 & 297.6 & 60.4 \\
\hline 2016 & 1592 & 1529.0 & 193.0 & 575.8 & 515.4 & 60.4 \\
\hline
\end{tabular}


The market share of agricultural insurance in the Krasnodar Krai totalled $10.1 \%$ (USA - 90\%, China - 45\%) (Glauber 2015, Agroinsurance international 2013).
The level of payments made $16.3 \%$ (USA $-52 \%$ of losses) $[1,2$, 3,11 ] with the agricultural production growth $104.5 \%$ (Table 6).

Table 6. The main indicators of the agricultural insurance market in terms of the subjects of the Russian Federation in 2016 [13]

\begin{tabular}{|c|c|c|c|c|c|c|}
\hline RF subjects & $\begin{array}{l}\text { Insurance premiums } \\
\text { (millions of Russian } \\
\text { roubles) }\end{array}$ & $\begin{array}{l}\text { Market } \\
\text { share }(\%)\end{array}$ & $\begin{array}{l}\text { The amount of subsi- } \\
\text { dies from the federal } \\
\text { budget } \\
\text { (millions of Russian } \\
\text { roubles) }\end{array}$ & $\begin{array}{l}\text { The share of subsidies } \\
\text { from the federal } \\
\text { budget }(\%)\end{array}$ & $\begin{array}{l}\text { The level of in- } \\
\text { surance payments } \\
(\%)\end{array}$ & $\begin{array}{l}\text { Insurance payments } \\
\text { (millions of Russian } \\
\text { roubles) }\end{array}$ \\
\hline $\begin{array}{l}\text { The Russian } \\
\text { Federation }\end{array}$ & 9822.0 & 100.0 & 2270 & 100.0 & 20.0 & 1964 \\
\hline $\begin{array}{l}\text { Krasnodar } \\
\text { Krai }\end{array}$ & 1529.0 & 15.6 & 515.4 & 22.7 & 34.5 & 528 \\
\hline Rostov Oblast & 120.0 & 1.2 & 31.4 & 1.4 & 22.9 & 27.5 \\
\hline $\begin{array}{l}\text { Volgograd } \\
\text { Oblast } \\
\end{array}$ & 6.5 & 0.06 & 3.3 & 0.14 & - & - \\
\hline $\begin{array}{l}\text { The Adyghe } \\
\text { Republic }\end{array}$ & 3.8 & 0.04 & - & - & - & - \\
\hline
\end{tabular}

The assessment of the tendencies of the development of agroindustrial complex in Krasnodar Krai showed that during the recent years there have been systematic risks of insufficient harvesting due to emergencies $[4,6,7,20]$.

The conducted analysis of the situation in the agricultural insurance market showed that the current system of agricultural insurance with state support is not effective and for the further development it is necessary to change significantly the existing mechanisms of agricultural risks insurance as well as the main approaches and principles of providing state support within the given direction.

The dynamic coordination of economic interests of participants of the regional market is realised in the course of optimising the relationship within the regional institutional environment, during the development of institutions and mechanisms, in the sphere of interaction of interests and criteria for stabilising the social and economic processes in the region as well as in developing industries, minimising insurance risks and increasing investment activity.

The aggregate index of the factorial model of the resource potential of the regional insurance market proposed by the authors is calculated using the following formula:

$I_{\mathrm{rprim}}=\left(I_{\mathrm{fs}} \times I_{\mathrm{cs}} \times I_{\mathrm{pi}} \times I_{\mathrm{ic}} \times I_{\mathrm{ip}}\right)^{1 / 5}$,

where $I_{\mathrm{fs}}$ is the index of financial stability of insurers;

$I_{\mathrm{cs}}$ - index of capital sufficiency;

$I_{\mathrm{pi}}$ - index of population income;

$I_{\text {ic }}$ - index of insurance capacity;

$I_{\mathrm{ip}}$ - index of investment potential.

The evolution of the insurance market in Krasnodar Krai will contribute to achieving the following goals:

— The increasing capitalisation of the regional insurance institutions;

- The participation of authorities of Krasnodar Krai in improving the legal base regulating the activities of subjects on the insurance services market in accordance with federal legislation and within their competence.

- Revalorisation of insurance culture of economic entities and citizens with the use of mass media, insurance propaganda;
- A major review of the positions of the Association of Insurance Institutions of Krasnodar Krai aimed at forming and developing of the regional insurance market.

\section{Conclusion}

In the context of traditional debates, the expansion of the sector of services that are provided to the policyholders is one of the essential objectives of the development of the regional insurance system. A regulator's action is a driving force of the development in the process of providing the improving quality of insurance services.

The increasing revenue of the insurance companies' budgets must result in enhancing of insurance reserves of insurance companies which make the basis for insurance contracts obligations fulfillment.

The authorities of the region must ensure that the free reserves of the insurers in the conditions of risk and uncertainty could be used on the territory of Krasnodar Krai as investment and credit resources.

In order to improve the investment policy that includes forming and implementing criteria for the creation of convenient investment space in the region it is necessary to coordinate the insurers' investments.

Thus, the order of placement of funds accepted as a result of selling mandatory types of insurance, especially personal households insurance, can minimise risks of their investment.

To promote the effective functioning of the insurance services market it is necessary to establish equal conditions on the territory of the region for implementation of activities for all the insurance companies that employ competent professionals in the insurance sphere.

\section{Conflict of Interest}

The authors confirm that the data do not contain any conflict of interest.

\section{References}

[1] Agroinsurance international. 2013. Available online: www.agroinsurance.com

[2] Best's Insurance Reports. International. An Explanation of the Best Value Rating System and Procedures. The Insurance Information Source. New Jersey: Oldwic, 2014. 
[3] Crop policies and pilots. Risk Mamagmet Agency. Washington D.C.: USDA, 2012. Available online: http://www.rma.usda.gov/policies/

[4] Decree of the Head of Administration (Governor) of Krasnodar Krai No. 944 of 05.10.2015 (Edition of September 16, 2016) "On the approval of the State Programme of Krasnodar Krai "Agricultural Development and Regulation of Agricultural Products, Raw Materials and Food Markets". 2016.

[5] European Motor Insurance Markets. 2015. Available online: https://www.insuranceeurope.eu/european-motor-insurancemarkets

[6] Federal Law No. 222-FL of 23 June 2016 "On State Support in the Sphere of Agricultural Insurance and on Amending the Federal Law "On the Development of Agriculture". 2016.

[7] Federal Law No. 424-FL of December 22, 2014 "On Amending the Federal Law "On State Support in the Field of Agricultural Insurance". 2014.

[8] J.W. Glauber. Agricultural Insurance and the World Trande Organization. 2015. Available online: http://www.ifpri.org/publication/agricultural-insurance-andworld-trade-organization

[9] Insurance Europe, Annual Report, 2014-2015. Available online: www.insuranceeurope.eu

[10] Indirect taxation on insurance contracts in Europe. 2015. Available online: https://www.insuranceeurope.eu/indirect-taxationinsurance-contracts-europe-2018

[11] N. Kirillova. Regulation of financial condition of insurers in the Russian Federation and assessment of insurers by the insured. Copernican Journal of Finance \& Accounting, 3(2), 2014, pp. 79-89.

[12] N.V. Lipchyu, L.K. Ulybina, O.A. Okorokova. Current state and prospects of the development of the insurance market of Krasnodar Krai in the conditions of economic modernisation. Finance and Credit, 41(473), 2011, pp. 31-35.

[13] Official website of the Federal State Statistics Service. Available online: http://www.gks.ru

[14] O.A. Okorokova, L.K. Ulybina. The formation and development of the insurance sector of the financial market in the reproductive process of the region's economy. Issues of Economics and Law, 6, 2013, pp. 101-110.

[15] O.A. Okorokova, L.K. Ulybina. The role of insurance market institutions in the economy. In the world of scientific discoveries, 11.4(59), 2014, pp. 1464-1483.

[16] O.A. Okorokova, L.K. Ulybina. Institutional development and financial stability of the Russian insurance market institutions. Science, Technology and Life Proceedings of the international scientific conference. 2015.

[17] Report on the state of the market of agricultural insurance carried out with state supportin the Russian Federation in 2016: Information brochure. Moscow: Ministry of Agriculture of Russia, FSBI "FASSISAP". 2017. Available online: http://www.fagps.ru/index.php/deyatelnost/otchety-odeyatelnosti

[18] Territorial body of the Federal State Statistics Service in Krasnodar Krai. Available online: http://krsdstat.gks.ru/wps/wcm/connect/rosstat_ts/krsdstat/ru/stat istics/

[19] The State Programme "Agricultural Development and Regulation of Agricultural Products, Raw Materials and Food Markets in Krasnodar Krai", approved by the Resolution of the Head of Administration (Governor) of Krasnodar Krai, 1204, 2013.

[20] The state programme of Krasnodar Krai "Creating conditions for ensuring the availability of financial services". 2015. 